\title{
Mapping of transcription start sites of human retina expressed
} genes

\author{
Valeria Roni*, Ronald Carpio and Bernd Wissinger
}

Address: Molecular Genetics Laboratory, University Eye Hospital, Roentgenweg 11, 72076 Tuebingen, Germany.

Email: Valeria Roni* - valeria.roni@uni-tuebingen.de; Ronald Carpio - neuro100cia@yahoo.com; Bernd Wissinger - wissinger@unituebingen.de

* Corresponding author

Published: 7 February 2007

BMC Genomics 2007, 8:42 doi:10.1 |86/|47|-2/64-8-42
Received: 26 October 2006

Accepted: 7 February 2007

This article is available from: http://www.biomedcentral.com/I47I-2/64/8/42

(c) 2007 Roni et al; licensee BioMed Central Ltd.

This is an Open Access article distributed under the terms of the Creative Commons Attribution License (http://creativecommons.org/licenses/by/2.0), which permits unrestricted use, distribution, and reproduction in any medium, provided the original work is properly cited.

\begin{abstract}
Background: The proper assembly of the transcriptional initiation machinery is a key regulatory step in the execution of the correct program of mRNA synthesis. The use of alternative transcription start sites (TSSs) provides a mechanism for cell and tissue specific gene regulation. Our knowledge of transcriptional initiation sequences in the human genome is limited despite the availability of the complete genome sequence. While genome wide experimental and bioinformatic approaches are improving our knowledge of TSSs, they lack information concerning genes expressed in a restricted manner or at very low levels, such as tissue specific genes.

Results: In this study we describe the mapping of TSSs of genes expressed in human retina. Genes have been selected on the basis of their physiological or developmental role in this tissue. Our work combines in silico analysis of ESTs and known algorithm predictions together with their experimental validation via Cap-finder RACE. We report here the TSSs mapping of 54 retina expressed genes: we retrieved new sequences for $4 \mathrm{I}$ genes, some of which contain un-annotated exons. Results can be grouped into five categories, compared to the RefSeq; (i) TSS located in new first exons, (ii) splicing variation of the second exon, (iii) extension of the annotated first exon, (iv) shortening of the annotated first exon, (v) confirmation of previously annotated TSS.

Conclusion: In silico and experimental analysis of the transcripts proved to be essential for the ultimate mapping of TSSs. Our results highlight the necessity of a tissue specific approach to complete the existing gene annotation. The new TSSs and transcribed sequences are essential for further exploration of the promoter and other cis-regulatory sequences at the 5 'end of genes.
\end{abstract}

\section{Background}

The spatial and temporal regulation of gene transcription is primarily determined by it's flanking promoter (cis-regulatory DNA elements) through interaction with trans-acting regulatory proteins (transcription factors) [1,2]. The start of transcription is accomplished by the formation of a pre-initiation complex on the DNA, yet our knowledge of transcriptional initiation sequences in the human genome is still limited despite the availability of the complete genome sequence $[3,4]$. Therefore one of the main remaining challenges is to locate these gene sequences, defined as the transcription start site (TSS), in order to explore core promoter and cis-regulatory elements that direct the start of every transcript. Genomic structure and full length cDNA sequences aligned on the genome provide opportunities to locate TSSs. Conventional methods 
for determining exact TSSs, such as 5' RACE or primer extension are laborious and are not selective for the complete transcript. Consequently, many mRNA sequences stored in public databases lack information about their genuine $5^{\prime}$ ends, mainly due to the difficulties in obtaining full-length cDNA. Several bioinformatic and experimental approaches have been developed to explore fulllength cDNAs and the human transcriptome [5]. Computational predictions may represent a powerful tool to localize first exons and TSSs on an averaged genome-wide scale $[6,7]$, however they may fail at the level of individual genes or in genes with complex regulatory patterns (e.g. multiple or tissue-specific TSS).

Recently a number of experimental approaches to compile TSSs on a genome-wide scale have been established including the Database of human Transcriptional Start Sites (DBTSS) [8], whole genome tilling array analysis [9], and the exploration of mouse and human CAGE tag libraries [10]. To enable future progress we need to complete and revise these catalogues with an accurate annotation of the 5' and 3'end, and include splice isoforms of the transcripts. In addition to genome wide approaches, there is a need for more specific studies, which cover tissue specific genes, expressed in a restricted manner. Identification of potential transcription signals that are tissue specific relies on the correct determination of transcriptional start sites.

In this work we describe an experimental approach to identify the TSSs of a selected group of genes, which are predominantly expressed in retina. We focused our attention on the human retina, due to its unique and specialised function. This complex tissue, composed of multiple, highly differentiated and specific cell types (e.g. rod and cone photoreceptors, amacrine cells, Mueller glial cells), expresses a large number of specific genes. Mutations in many of these genes result in blinding disorders. The subset of genes expressed in human retina has been partially elucidated $[11,12]$, with a number of studies defining genes that are either highly expressed in retina or which pose a crucial target of transcription factors in this tissue [13-16]. We selected a pool of retina expressed genes and employed Cap selective RACE to ensure amplification and subsequent cloning of genuine TSSs. We describe herein the results of this analysis, reporting the correct TSSs within this group of retinal transcripts.

\section{Results}

\section{Genes Selection and in silico assembly}

76 annotated genes were selected for analysis. The selection was done based on the following criteria: (i) specific or high levels of expression in retina, (ii) a role in retina specific physiological processes or retinal development, and (iii) involvement in retinal disease. A compilation of all tested genes including gene symbol, definition, chromosomal location and tissue/cell type of expression is shown in Additional file 1.

cDNA and transcript sequences available in public databases (RefSeq, NCBI and Ensemble gene predictions covered by at least one EST, Unigene ESTs database) were downloaded and new assemblies generated using SeqMan.

We found that $5^{\prime}$ transcript termini represented in public datasets can be readily identified by clusters of cDNA ends in the assemblies. Additionally, the information about putative TSSs was assessed in The Eukaryotic Promoter Database [17] and Database of Transcriptional Start Sites (DBTSS) [8]. These data were compiled to create a preliminary gene model which was used to design primers for the subsequent Cap-finder RACE experiments.

\section{Experimental examination of TSSs}

Cap-finder RACE cDNA fragments were cloned and a variable number of clones were sequenced for each gene, depending on the number and the sizes of the colony PCR products detected on the gel. We obtained products for 54 genes out of the 76 genes analysed. A summary of the results obtained with Cap-finder RACE is shown in Tables 1. Genes for which the promoter and TSS were already known (RHO and OPN1SW) served as internal positive controls. For each gene we detected at least one splice variant that agreed with one or more RefSeq annotated exons.

Our strategy relies on the location of gene specific primers within internal exons. We obtained those cDNA products that covered at least one exon-exon junction and thus ruled out the possibility of amplification of genomic contamination. This strategy has enabled us to identify alternatively spliced $5^{\prime}$ ends that arise from tissue specific gene expression and regulation.

Table 1 lists the results of the Cap-finder RACE experiments for 54 retinal expressed genes and the corresponding RefSeq entry (database release 18). These results can be grouped into five categories with reference to RefSeq; (i) new TSSs within novel exons (8 genes), (ii) alternative splice form of the second exon (2 genes: IMPG1, SAG), (iii) extension of the annotated first exon (27 genes), (iv) length shortening of the annotated first exon (4 genes), (v) confirmation of previously annotated TSSs (13 genes). Table 1 provides the exact nucleotide positions of $5^{\prime}$ termini of the Cap-finder RACE cDNA clones referring to the UCSC Human Genome Browser (March 2006 assembly). In defining the interval where TSSs are located we report the start, and when present, the internal frequent start and end nucleotide position of each TSS. Sequences from this 
Table I: Results of the RACE experiment to determine the TSS of retina transcripts

\begin{tabular}{|c|c|c|c|c|c|c|c|c|}
\hline \multirow[t]{2}{*}{ Gene Symbol } & \multirow[t]{2}{*}{ RACE results } & & \multicolumn{3}{|c|}{ TSS location } & \multirow[t]{2}{*}{ Chr. } & \multirow[t]{2}{*}{ Shape } & \multirow[t]{2}{*}{ CAGE } \\
\hline & & & Start & Int. peak & End & & & \\
\hline \multirow[t]{3}{*}{ Clorf32 } & Two new first exons & Isoform a & $|65,208,79|$ & & & lq24.| & $\mathbf{S P}$ & + \\
\hline & & Isoform b & $165,269,346$ & & & & - & - \\
\hline & $\begin{array}{l}\text { Extension exon } 0 \text { of } \\
180 \mathrm{bp}\end{array}$ & Isoform a & $98,329,050$ & & $98,329,083$ & $2 q 11.2$ & BR & + \\
\hline \multirow[t]{2}{*}{ CNGA3 } & & Isoform b & $98,329,288$ & & & & SP & - \\
\hline & & Isoform c & $98,329,371$ & & & & SP & + \\
\hline \multirow[t]{2}{*}{ DHRS3 } & New first exon & Isoform a & $12,578,722$ & & & Ip36.I & SP & - \\
\hline & $\begin{array}{l}\text { Shorter exon I of } 508 \\
\text { bp }\end{array}$ & Isoform b & $12,599,903$ & & $12,599,935$ & & SP & - \\
\hline ELOVL5 & New first Exon & & $53,320,946$ & & & $6 p 21.1-p 12.1$ & - & - \\
\hline \multirow[t]{2}{*}{ KIFC3 } & Two new first exons & Isoform a & $56,437,970$ & & & $|6 q| 3-q 2 \mid$ & SP & - \\
\hline & & Isoform b & $56,370,953$ & & & & SP & - \\
\hline \multirow[t]{3}{*}{ RCVI } & $\begin{array}{l}\text { Extension exon I of } \\
203 \mathrm{bp}\end{array}$ & Isoform a & $9,749,613$ & $9,749,402$ & $9,748,934$ & $|7 p| 3 . \mid$ & PB & - \\
\hline & New first Exon & Isoform b & $9,745,910$ & & & & - & - \\
\hline & $\begin{array}{l}\text { Lack of exon I. exon } 2 \\
\text { extended }\end{array}$ & Isoform c & $9,745,244$ & & $9,745,221$ & & MU & - \\
\hline \multirow[t]{2}{*}{ RDHI 2} & Two new exons & & $67,254,268$ & $67,254,276$ & $67,257,284$ & |4q24.| & MU & - \\
\hline & & Isoform c & $19,778,103$ & & & $9 p 22-p 13$ & SP & - \\
\hline \multirow[t]{4}{*}{$S L C 24 A 2$} & Two new first exons & Isoform a & $19,778,808$ & & & & - & - \\
\hline & & Isoform b & $19,778,609$ & & & & - & + \\
\hline & & Isoform d & $19,776,949$ & & $19,777,002$ & & PB & + \\
\hline & Lack of exon 2 & & $76,839,115$ & & $76,839,078$ & $6 q 14.2-q 15$ & SP & - \\
\hline \multirow[t]{2}{*}{ IMPGI } & $\begin{array}{l}\text { Lack of exon I. } \\
\text { shortening exon2 }\end{array}$ & & $76,808,496$ & & & & SP & - \\
\hline & $\begin{array}{l}\text { Complete in the first } 3 \\
\text { Exons }\end{array}$ & & $76,839,060$ & & & & - & - \\
\hline SAG & Lack of exon 2 & & $233,998,462$ & & $233,998,525$ & $2 q 37.1$ & BR & - \\
\hline AIPLI & & $61 \mathrm{bp}$ & $6,279,208$ & & $6,279,306$ & $17 p \mid 3.1$ & - & - \\
\hline$A O C 2$ & & $10 \mathrm{bp}$ & $38,250,126$ & & & $|7 q 2|$ & SP & + \\
\hline CLULI & & $31 \mathrm{bp}$ & 606,669 & 606,693 & 606,698 & $|8 p| \mid .32$ & PB & - \\
\hline CNGB3 & & $43 \mathrm{bp}$ & $88,404,286$ & & $88,404,354$ & $8 q 21-q 22$ & - & - \\
\hline EYA3 & & $14 \mathrm{bp}$ & $28,287,732$ & & $28,287,684$ & $1 p 36$ & BR & + \\
\hline FSCN2 & & $66 \mathrm{bp}$ & $77,109,947$ & & $77,109,997$ & $17 q 25$ & - & - \\
\hline GNATI & & $44 \mathrm{bp}$ & $50,204,027$ & & $50,204,047$ & $3 p 21$ & - & - \\
\hline GRK7 & & $40 \mathrm{bp}$ & $142,979,632$ & & $142,979,726$ & $3 q 21-q 23$ & BR & - \\
\hline GUCAIB & & $19 \mathrm{bp}$ & $42,270,691$ & $42,270,689-42,270,672$ & $42,270,649$ & $6 p 21.1$ & PB & - \\
\hline
\end{tabular}


Table I: Results of the RACE experiment to determine the TSS of retina transcripts (Continued)

\begin{tabular}{|c|c|c|c|c|c|c|c|c|}
\hline GUCY2D & & $30 \mathrm{bp}$ & $7,846,687$ & & & $|7 p| 3.1$ & - & - \\
\hline HPCA & & $15 \mathrm{bp}$ & $33,124,670$ & & $33,124,680$ & $2 p 25.1$ & MU & + \\
\hline IMPDHI & & $206 \mathrm{bp}$ & $127,837,736$ & & & $7 q 31.3-q 32$ & SP & + \\
\hline IMPG2 & & $23 \mathrm{bp}$ & $102,522,132$ & & $102,522,102$ & $3 q|2.2-q| 2.3$ & $\mathbf{B R}$ & - \\
\hline LRRC2I & Extension exon I of & $121 \mathrm{bp}$ & $85,991,318$ & $85,991,280$ & $85,991,194$ & $10 q 23$ & PB & - \\
\hline MPP4 & & $30 \mathrm{bp}$ & $202,271,692$ & $202,271,616$ & $202,27 I, 60 I$ & $2 q 33.2$ & PB & - \\
\hline OPN4 & & 67 bp & $88,404,287$ & & & $10 q 22$ & SP & - \\
\hline PDC & & $17 \mathrm{bp}$ & $184,696,879$ & & $184,696,869$ & Iq25.2 & MU & - \\
\hline PDE6H & & $7 \mathrm{bp}$ & $15,017,238$ & & $15,0 \mid 7,243$ & $12 p \mid 3$ & SP & - \\
\hline PRPF3I & & 117 bp & $59,310,532$ & & $59,310,609$ & $19 q 13.42$ & MU & - \\
\hline RdCVF & & 37 bp & $17,432,763$ & $17,432,753-17,432,735$ & $17,432,716$ & $19 p \mid 3.11$ & MU & - \\
\hline RDH5 & & 39 bp & $54,400,449$ & & & $|2 q| 3-q \mid 4$ & SP & - \\
\hline RDH8 & & $63 \mathrm{bp}$ & $9,984,862$ & $9,984,925$ & $9,984,991$ & $19 p|3.2-p| 3.3$ & MU & - \\
\hline RDS & & $61 \mathrm{bp}$ & $42,798,348$ & & $42,798,296$ & $6 p 21.2-p \mid 2.3$ & BR & - \\
\hline RLBPI & & $83 \mathrm{bp}$ & $87,566,008$ & & 87,565888 & $15 q 26$ & - & - \\
\hline ROMI & & $215 \mathrm{bp}$ & $62,136,883$ & & $62,137,111$ & $|I q| 3$ & BR & - \\
\hline RPGR & & 7 bp & $38,071,739$ & & $38,071,704$ & XpII.4 & BR & - \\
\hline TULPI & & 70 bp & $35,588,693$ & & $35,588,651$ & $6 p 21.3$ & PB & + \\
\hline CRB2 & & 52 bp & $125,158,322$ & & $125,158,324$ & $9 q 33.2$ & - & - \\
\hline$C R X$ & Shortening exon I of & $60 \mathrm{bp}$ & $53,016,971$ & $53,017,001$ & $53,017,005$ & $19 q 13.3$ & SP & - \\
\hline$R P I$ & & $53 \mathrm{bp}$ & $55,691,206$ & & $55,691,233$ & $8 q|1-q| 3$ & BR & + \\
\hline WDRI7 & & 77 bp & $177,224,132$ & $\mid 77,224,169-177,224,185$ & $177,224,202$ & $4 q 34$ & MU & + \\
\hline ABCA4 & & & $94,359,290$ & & $94,359,245$ & $|p 22|-.p 2 \mid$ & BR & - \\
\hline CI4ORF2 & & & $103,457,619$ & & & $14 q 32.33$ & - & + \\
\hline CIQL2 & & & $119,632,934$ & & & $2 q 14.2$ & - & - \\
\hline C7orf9 & & & $25,427,912$ & & & $7 p 21-p 15$ & - & - \\
\hline CHM & & & $85,189,194$ & & $85,189,222$ & $X q 21.2$ & BR & + \\
\hline ELOVL4 & & & $80,7 \mid 4,034$ & & & $6 q 14$ & - & + \\
\hline OPNISW & Previous 5' end confirmed & & $128,203,084$ & & & $7 q 31.3-q 32$ & SP & - \\
\hline RAX & & & $55,091,570$ & & & $18 q 21.32$ & SP & - \\
\hline RBP3 & & & $48,010,989$ & & $48,011,000$ & $10 q \mid 1.2$ & - & - \\
\hline RDHII & & & $67,232,201$ & & $67,232,186$ & $14 q 24.1$ & SP & - \\
\hline $\mathrm{RHO}$ & & & $130,730,174$ & & & $3 q 21$ & SP & - \\
\hline RPLI4 & & & $40,473,831$ & & & $3 p 22$ & SP & + \\
\hline RSI & & & $18,600,144$ & & & Xp22.2-p22.I & SP & - \\
\hline
\end{tabular}

The Table provides Gene Symbols of the processed genes, RACE results referring to the RefSeq entry (database release 18), nucleotide position of the TSS (start, internal frequent start and end) referring to the UCSC Human Genome Browser (March 2006 assembly), Chromosomal location (Chr.), shape of the TSS (Shape) according to the classification of Carninci et al., 2006: single peak [SP], broad [BR], bimodal/multimodal [MU], broad with dominant peak shape [PB], comparison with Cage TSS database (+ for correspondence, - no correspondence). The genes are listed according to the type of results that was obtained according to the description in the text: (i) new TSSs within novel exons (8 genes), (ii) alternative splice form of the second exon ( 2 genes:, (iii) extension of the annotated first exon ( 27 genes), (iv) length shortening of the annotated first exon ( 4 genes), (v) confirmation of previously annotated TSSs (13 genes). 
study have been submitted to GenBank under the accession numbers: DQ067456-DQ067464, DQ426859DQ426897, DQ980599-DQ980621.

\section{Retinal expressed genes with new 5' exons}

For 8 genes (C1orf32, CNGA3, DHRS3, ELOVL5, KIFC3, $R C V 1, R D H 12, S L C 24 A 2)$ we have identified a new exon composition at the $5^{\prime}$ end of the transcript and in some cases new untranslated 5' exons that locate the TSS several kilobases upstream or downstream from the annotated one.

- C1orf32. This transcribed locus in chromosome 1 was selected for its retinal expression. For this gene, whose function is still not characterised, we retrieved two new isoforms lacking the first annotated exon found in RefSeq. These isoforms contain TSSs in two new exons. One form displays a new first exon located $3 \mathrm{~kb}$ downstream from the previous TSS. The other form presents a first exon located 58,4 kb upstream of the former TSS, generating a new first intron spanning a locus transcribed in the opposite strand, the gene MAEL. (Figure 1A)

- CNGA3 (cyclic nucleotide gated channel alpha 3) codes for the $\alpha$-subunits of the cone photoreceptor cGMP-gated channel, a crucial component of the cone phototransduction cascade in colour vision. Mutation in this gene causes achromatopsia. The RACE experiment confirmed the presence of 4 isoforms, all containing a splicing of untranslated exon 0 localised 23,4 kb upstream of exon 1 [18] (Figure 1B).

- RDH12 (Retinol dehydrogenase 12) is an enzyme with dual-specificity retinol dehydrogenases that metabolise both all-trans- and cis-retinols, reported to be expressed in photoreceptors [19]. Mutations within RDH12 cause both recessive early onset Retinitis pigmentosa and Leber's congenital amaurosis $[20,21]$. In human retinal mRNA we retrieved two forms of the transcripts containing a new first exon located upstream of the RefSeq TSS and a differentially spliced second exon. The in silico assembly and experimental pipeline allowed us report three putative TSSs for this gene; the first is defined by the RefSeq annotation, the second was deduced from the most upstream transcript represented by ESTs from pooled colon and the third is a new TSS displayed by retinal transcripts (Figure 1C).

- DHRS3 (dehydrogenase/reductase, SDR family, member 3) codes for an enzyme catalysing the reduction of alltrans-retinal to all-trans-retinol in the presence of NADPH $[19,22]$. The gene was included in our study for its high expression in retina. Cap-finder RACE confirmed the previous first exon and TSS. We also detected an alternative TSS in a new first exon downstream from the annotated one which was predicted with FirstEF [6]. (Additional file 2: Figure 5).

- ELOVL5 (elongation of long chain fatty acids, including docosahexanoic acid (DHA), family member 5). This gene was recently annotated as a retinal expressed gene [23] and a target of mutation studies in retinitis pigmentosa [24]. We detected a new form of the transcript with a new first exon that was not previously annotated or described for retina. (Additional file 3: Figure 6)

- KIFC3 (Kinesin family member C3) codes for a retina specific microtubule-associated force-producing protein that may play a role in intracellular transport [25]. We have characterised two new isoforms of KIFC3 retinal transcripts which lack the first 3 exons annotated in RefSeq. Both transcripts include a new first exon that localizes these new TSSs $44 \mathrm{~kb}$ upstream and $27 \mathrm{~kb}$ downstream respectively from the TSS referenced in the RefSeq database. The more upstream start site locates the gene in proximity to another retina specific gene (CNGB1). (Additional file 4: Figure 7)

- RCV1 (recoverin) inhibits rhodopsin kinase activity in retinal photoreceptors by reducing the binding of arrestin to rhodopsin. Deregulation of recoverin expression in certain types of cancer demonstrates a pathological role in cancer-associated retinopathy [26]. Although a previous study of the promoter was performed [27], no clear evidence of the TSS have been described. For this gene we detected three alternative transcripts; the first with the same 5 ' end as the previously annotated TSS (first exon length may vary from 203 bp longer to 444 bp shorter), the second with a more frequent isoform lacking the first exon and starting 80 bp upstream from the second exon of the RefSeq and the third form has a new first exon located downstream from the annotated one. (Additional file 5: Figure 8).

- SLC24A2 (solute carrier family 24, sodium/potassium/ calcium exchanger, member 2) codes for a potassiumdependent sodium-calcium exchanger in cone photoreceptor [28]. Although variant alleles of the cone SLC24A2 gene have been identified, none of them are definitively associated with a specific retinal disease [29]. The new model we present for SLC24A2 predicts three putative TSSs located in two new additional exons that are alternatively spliced (Additional file 6: Figure 9).

We also investigated whether the new exons that extend the 5 ' end of the transcript may introduce new potentially protein coding sequences. We didn't observe in any case an extension of the open reading frame beyond the annotated start codon. However short alternate open reading frames of at least 40 codons were observed for C1orf32 

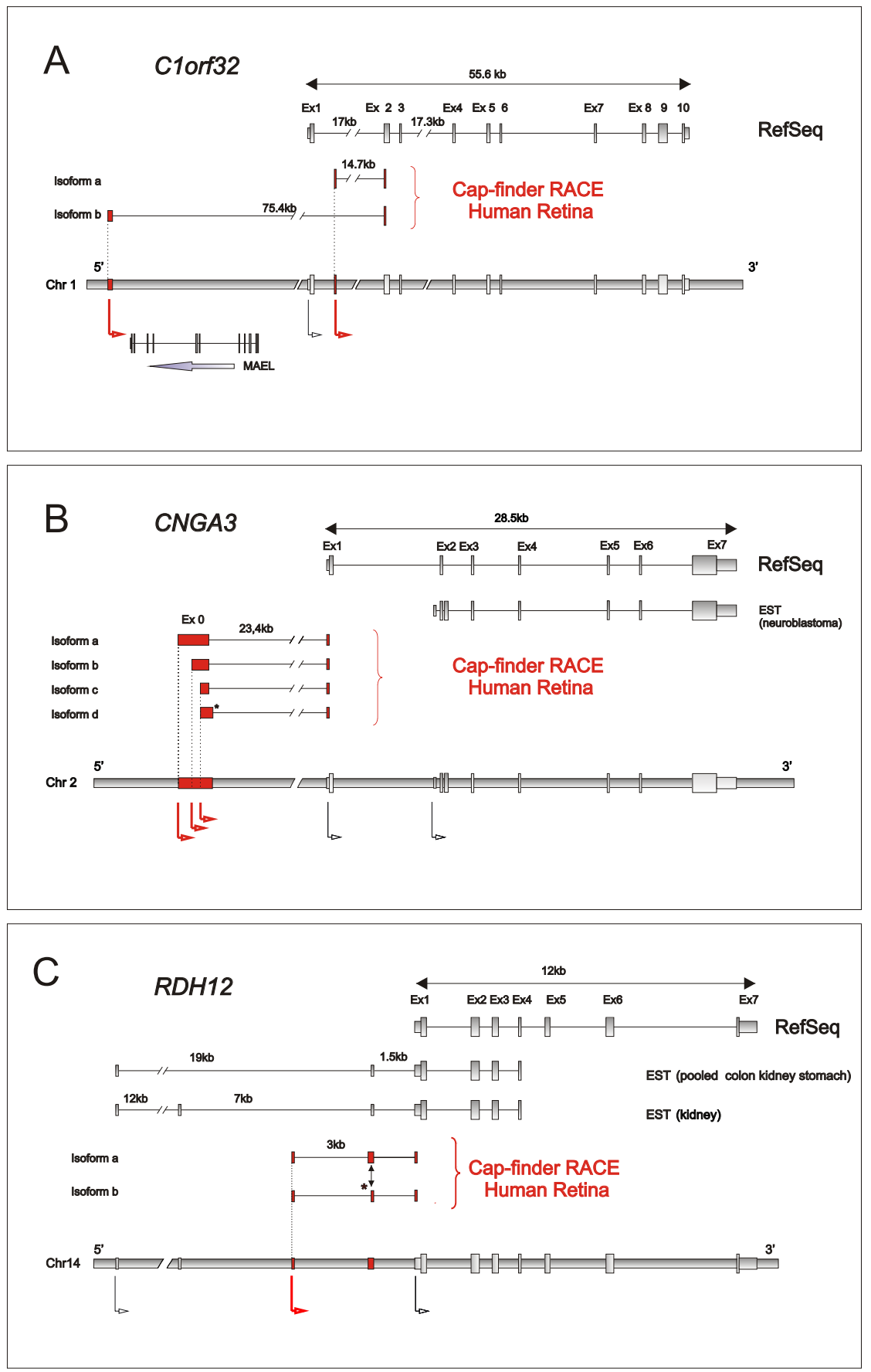

\section{Figure I}

Schematic gene structure of 3 analysed genes. Schema of the RefSeq, ESTs, exonic structure of new isoforms identified with the Cap-finder RACE of human retina mRNA and the genomic structure containing the TSSs indicated by arrows. Red Arrows indicate new retina TSSs. A) Clorf32. Transcripts in human retina: isoform a contains a new first exon located $2.7 \mathrm{~kb}$ downstream from previous TSS, isoform b presents a first exon $58,5 \mathrm{~kb}$ upstream the previous TSS. This second transcript defines an intron containing another transcribed locus in the opposite strand, the gene MAEL. B) CNGA3: Cap-finder RACE of human retina mRNA confirmed the presence of an untranslated exon localised 23,4 kb upstream of exon I. One isoform contains alternatively spliced variant of exon 0 (asterisk). C) RDH I2: the schematic representation of EST from human retina shows two forms of the transcripts starting in a new retina TSS. These two isoforms contain two alternatively spliced variants of the second exon (asterisk). 
(nucleotide position 18-290 from the TSS in isoform a, and position 164-400 in isoform b), CNGA3 (position 166-315), DHRS3 (position 166-315), KIFC3 (position 4-195), and SLC24A2 (position 55-183 isoform a, 44289 isoform b). Yet the translated sequences of these short ORFs do not have homology with any protein in public databases.

\section{Detection of novel splicing variants and shorter transcripts} Our experimental procedure described alternatively spliced isoforms for two genes IMPG1, SAG, which lack exon 2 of the RefSeq. These forms have not been annotated in the RefSeq database. We confirmed these alternatively spliced isoforms by regular RT-PCR (Data not shown). The second exon of the gene SAG contains the TSS and the presence of this alternative form, lacking the regular start site, may play a role in the regulation and further processing of the transcript. For 4 genes (CRB2, CRX, $R P 1, W D R 17)$, we detected shorter transcripts that lack the annotated start codon. Since these experiments were done with the same adapter ligated first-strand cDNA we assume that these short transcripts are derived from true alternative TSSs. These transcripts may be preferentially amplified in the RT-PCR and may be translated from an internal initiation codon. We report in Table 1 the detailed results for these genes.

\section{Confirmation of results with primer extension}

To provide an experimental validation of our results we undertook primer extension experiments. We performed reverse transcription of mRNA with a sequence-specific FAM-labelled primer for two genes (CNGA3, RDH12). The length of the FAM-labelled cDNA primer extension product can be analysed on ABI-DNA Genetic Analyser using GeneScan software. As a result of the analyses we detected a fragment of $350 \mathrm{bp}$ for CNGA3 (Fig 2A) and a fragment of $215 \mathrm{bp}$ for RDH12 (Figure 2B). The size of these fragments confirms the presence of the transcripts that we detected with RACE.

\section{Comparison with existing annotations and databases}

To assess the quality of current annotations of the 5 ' end of genes expressed in human retina, the sequences obtained by 5' RACE were compared with the corresponding gene annotation/prediction. Overall, RACE experiments detected 15 exons that were neither annotated nor predicted for retina transcripts; 8 exons did not have any matching experimental evidence in GenBank, while the other 7 showed different boundaries or alternative splice sites. Of these 15 un-annotated exons, 12 are first exons and can be considered the new first exon for the retinal transcripts. Of the 54 genes successfully amplified, 41 (76\%) delivered 5' RACE sequences different from the annotation. Results of a parallel project, DBTSS [8], supported our results concerning 3 of these genes (CNGA3,
ELOVL5 and SLC24A2) although the source of mRNA was not human retina. We extended the annotated first exon of 27 RefSeq genes by an average of 60 transcribed bases. We compared our results with genome wide mapping of TSSs using CAGE tags [10]. We found perfect correspondence for 13 transcript isoforms; for another 6 transcripts the start site retrieved in the CAGE database is located less than 400 bp away. For 35 transcript isoforms the TSS is located in a different position (See Table 1). This discrepancy in the results may be due to the fact that the CAGE database doesn't include retina amongst the panel of analysed tissues and therefore lack specific and rare transcript isoforms present in that tissue.

\section{Shape of TSSs and conservation}

After analyzing the distribution of RACE clones we could define the shape of TSSs according to the classification previously reported [10]. The different clones were clustered and depending on the start base position of each clone within a cluster we divided the start sites into four shapes. In the single dominant peak class (SP) the majority of clones are concentrated to no more than four consecutive start positions with a single dominant TSS. The clusters spanning a broader region are grouped in a general broad distribution (BR), a broad distribution with a dominant peak (PB) and a bi- or multimodal distribution (MU): 22 genes showed a single dominant peak, 11 a broad distribution, 8 a bi-multi peak distribution and 6 a broad distribution with a dominant peak. For some transcripts we could not make a classification because the number of clones was less than 5 . We report the results of this analysis Table 1 (TSS shape). Figure 3 shows a graphical view of TSSs identified for AOC2, ABCA4, RDH12, and $L R R C 21$ as an example of the different distributions observed. The classification of the shape of TSSs defined by distribution of $5^{\prime}$ end RACE clones within a cluster is useful for the further characterization of expression regulation. The distribution of the clones defines different elements of the core promoter and gives insights on the start of transcription. Even if broad promoters are the major class in mammals [10], 36 of the analysed transcripts present a dominant peak highlighting the possibility that those transcripts are tightly regulated.

Although TSSs of orthologous genes do not necessary reside on equivalent locations because of evolution of mammalian TSSs [30], we analysed sequence conservation of the first new exons among a set of mammals (mouse, dog, cow): the range of conservation varies between 42 and $89 \%$. We report the pairwise alignment percentage of identity in Additional file 7.

Sequences residing upstream and downstream from the boundaries of new defined exons are regions displaying high regulatory potential calculated by a computational 


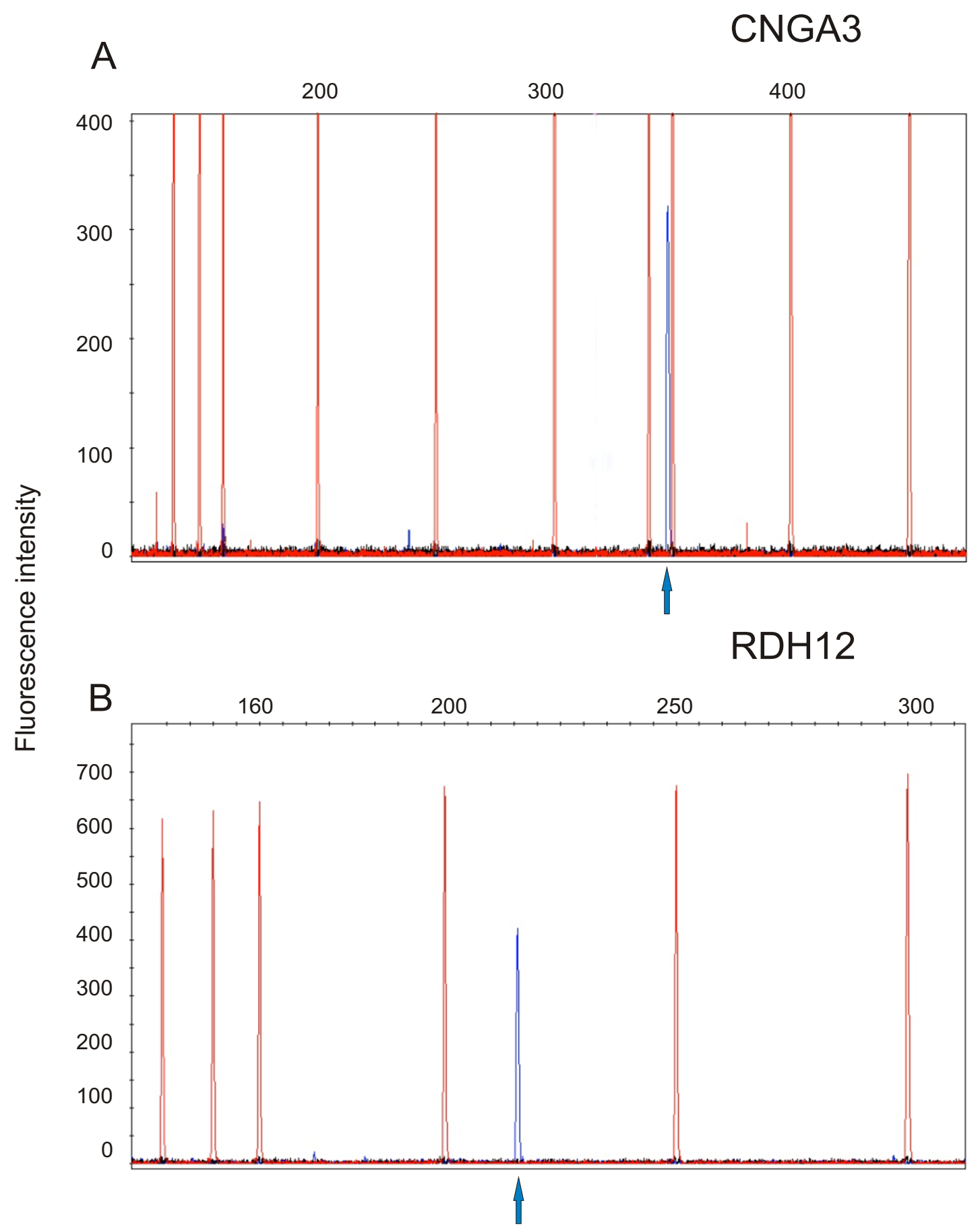

Lenght of the fragment in nucleotides

Figure 2

Primer extension results from WERI-RB I retina cell lines mRNA. Primer extension products obtained with the gene specific primer for CNGA3 (A) and for RDHI2 (B). The blue peaks in each panel correspond to the primer extension product (FAM-labelled cDNA). The elongation products size 350 bp and 215 bp were respectively expected from the data of RACE CDNA sequences (Blue arrow). Red peaks are the GeneScanR-500 ROX internal lane standards. In the $y$-axis is indicated the intensity of fluorescence, in the $\mathrm{x}$-axis the number of nucleotides. 

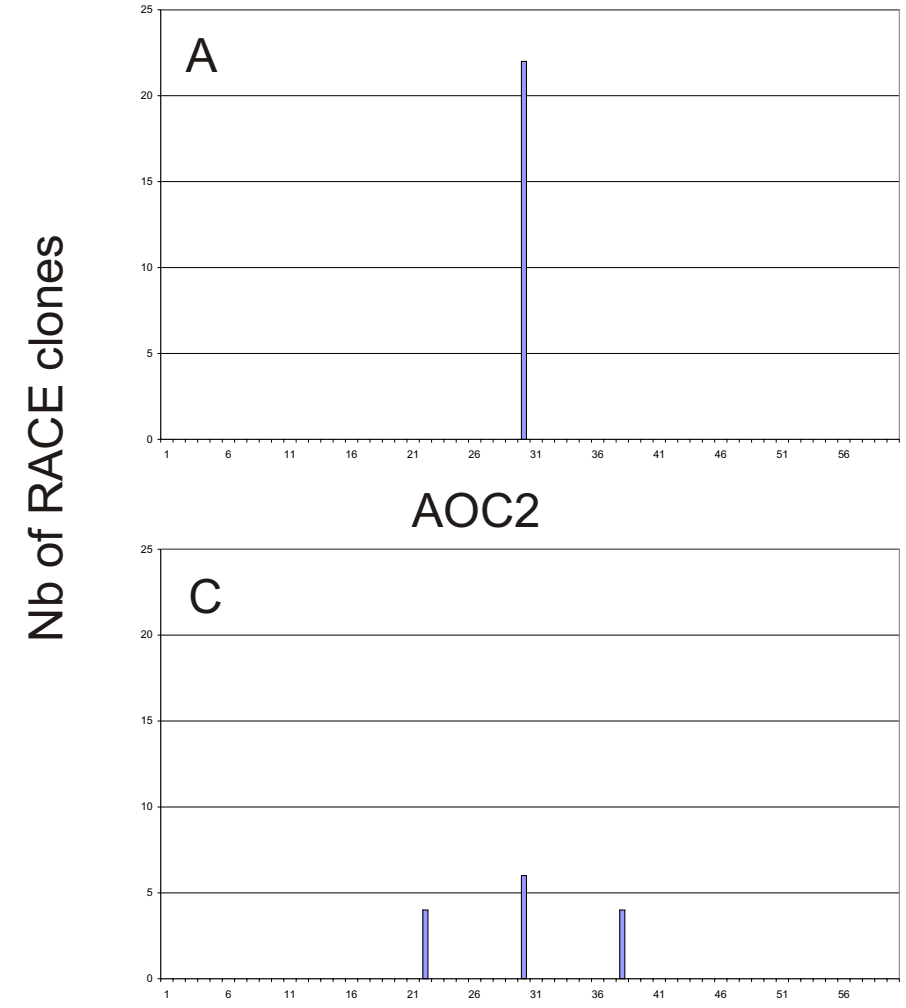

$\mathrm{RDH} 12$

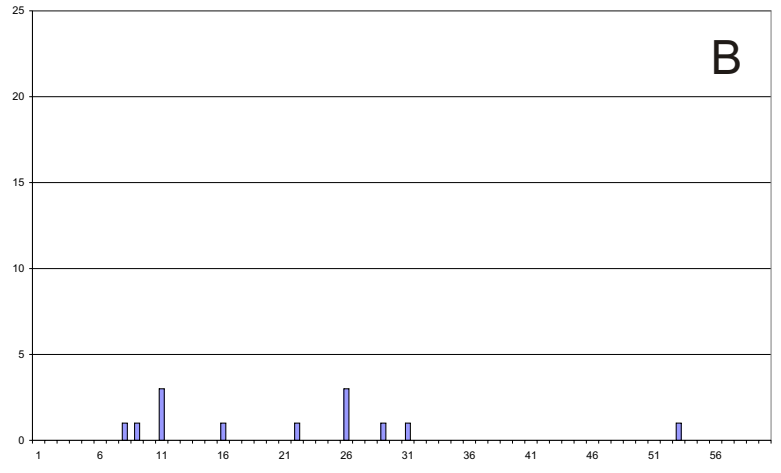

ABCA4

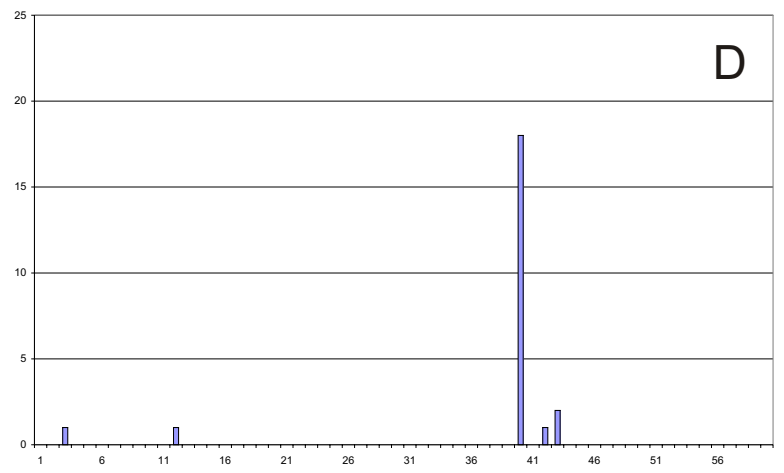

LRRC21

\section{Nucleotide position}

\section{Figure 3}

TSSs present different shapes. Histograms indicate the number of RACE clones mapping at each nucleotide position. Examples show the different pattern that we observed during the analysis of the Cap-finder RACE. A) Clones distribution for AOC2 (single peak class: SP). B) Clones distribution for ABCA4 (broad: BR). C) Clones distribution for RDHI2 (multimodal: $\mathrm{MU})$. D) Clones distribution for LRRC2I (broad with dominant peak shape: PB).

algorithm [31] integrated in the UCSC genome browser. The regulatory potential (RP) scores computed for the 500 bp sequence upstream the TSS shows that in 9 new first exons out of 11 the RP value exceeds an arbitrary threshold of 0.2 (data not shown). Considering 500 bp downstream the splice site of the first exon the RP value is $>0,2$ at least for 7 first exons out of 11 . This observation confirms the importance of the new described exons to locate new regulatory elements that are important for transcription in retina.

A high level conservation was observed for splice donor sites of the new first exon. 5 genes show an average conservation of at least $75 \%$ in the region $-3 /+5$ spanning the splice donor site. For example, we report an inter-species alignment of the 3' end of exon 0 (CNGA3). The sequence conservation at the level of the splice donor site highlights the possibility of a particular role for this splicing (Figure 4).

\section{Discussion}

Now that the information pertaining to the genomes of human and other animals is available, the next challenge for genetic studies is to map the TSSs and regulatory sequences of the genes. Here, we carried out a study to determine the genuine TSSs of a pool of retinal expressed genes. The results give correct information about the complete 5 ' end of transcripts and this data will be useful to locate the respective core and proximal promoter elements. We chose Cap-finder RACE to map the TSS of retinal expressed genes because this technique is selective for the complete transcript [8,32]. For 41 out of 54 successfully amplified genes, the Cap-finder RACE experiments detected transcripts which are different from the current 


\section{Human \\ Mouse \\ Rat \\ Rabbit \\ Dog \\ Cow \\ Elephant \\ Tenrec}

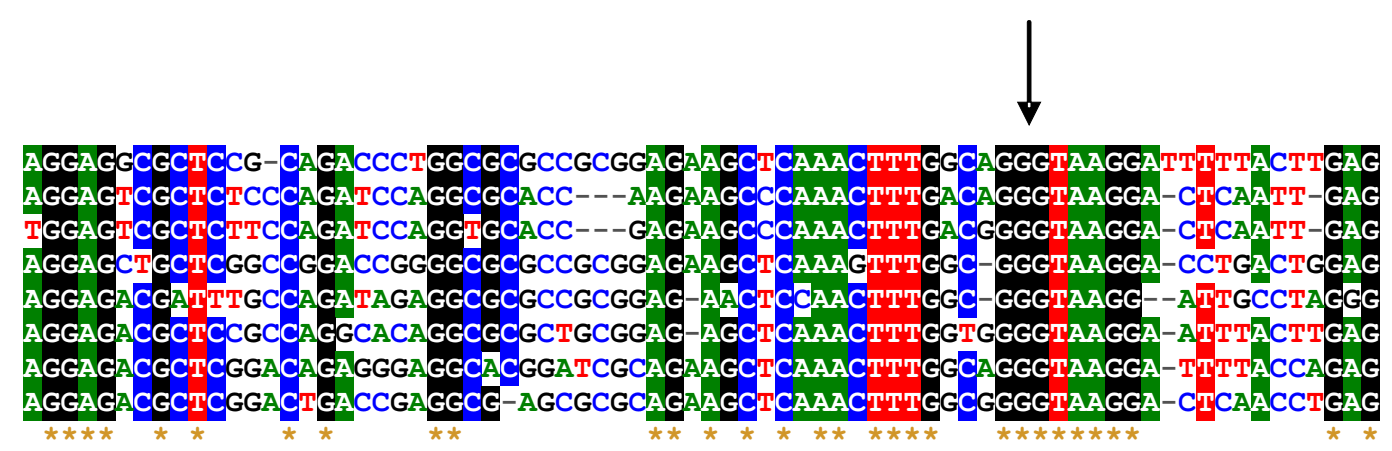

\section{Figure 4}

Inter-species alignment of exon-intron boundaries of the exon 0 of CNGA3. Conserved nucleotides are labelled with colours and with the star in the bottom those conserved in all the analysed species (human, mouse, rat, rabbit, dog cow, elephant and tenrec). Arrow highlights the splice donor site.

gene annotation In most cases the RefSeq was incomplete. Transcripts were missing part of the first exon or even complete exons at the $5^{\prime}$ end. This experimental determination of TSSs shows that the current gene annotation was in most cases obtained from data sources that are not strictly selective for the complete transcribed form, and need to be updated. This procedure led us to discover several transcript isoforms that were un-annotated and to locate retina specific TSSs. Proteins encoded by these genes are essential for retina function and stability. A mutation in the cis-regulatory elements may influence the level of transcription and have a strong effect due to sensitivity of photoreceptors for high level transcription of genes involved in phototransduction. The new described cis-regulatory regions and untranslated exons are possible targets for mutation studies in retinal disorders. Therefore new isoforms give a more complete picture of alternative start sites use in retina genes. The 5 ' untranslated region may contain important transcriptional and post transcriptional regulatory sites [33-35] and therefore only the complete 5' UTR provides the opportunity to study the potential regulatory role of these non-coding sequences. New reported TSSs contribute to the identification of regulatory elements active in tissue specific gene regulation $[36,37]$. Moreover, bioinformatics tools that identify common regulatory elements rely on the correct determination of TSSs within a particular tissue [38], therefore these computational approaches will only be effective after experimental validation of the 5 ' end of transcripts.

\section{Conclusion}

We herein report the TSSs for 54 retina expressed genes. Our results define new and more precise locations of TSSs for $76 \%$ of the analysed genes; moreover in $15 \%$ of the genes we found new exons in the 5 ' end of the transcripts. Thus, this analysis of TSSs in human retina was essential to define the complex pattern of transcripts present in this tissue.

Our results highlight the importance of applying a tissue specific approach with a systematic program of Cap-finder RACE using the known gene structures as a starting point and/or gene predictions to complete the existing gene annotation. The new TSSs and transcribed sequences provide crucial information for further exploration of the promoter and other cis-regulatory sequences at the 5'end of the gene, and in particular for the study those elements that are functionally active in human retina.

\section{Methods \\ In silico analysis}

We used available public database information (RefSeq, NCBI and Ensemble predictions covered by at least one EST, Unigene EST database) to perform in silico assembly and analysis of 5 'transcript termini. The procedure involves downloading the sequences from public databases, clustering them to obtain a consensus and designing a gene model with the most complete 5 ' transcript termini. Sequences were downloaded and assembled using the SeqMan program (DNAstar). In our analysis we consider retina ESTs as well as non-retinal ESTs to obtain the most complete information about the different alternative start sites already mapped. Additionally, the information about putative TSS was assessed using Promoser [39], Eukaryotic Promoter Database Current Release 87 [40], and Database of Transcriptional Start Sites DBTSS [41]. First exon boundaries were determined by aligning the predicted sequence to the genome using BLAT [42]. The gene model was then deduced considering the clustering of all the collected sequences giving the priority to the most accurate database in the 5 ' termini (EPD and DBTSS), but considering also gene prediction (GENS- 
CAN, implemented in the UCSC Genome Browser) and gene annotation that are confirm by at least one EST [43]. To evaluate first exons conservation we used BioEdit pairwise and multiple alignments [44]

\section{Primer design}

Gene specific reverse primers were selected within exons other than the first exon to obtain spliced products. Two primers were chosen for each gene, in order to perform a nested PCR, which allows to enhance specificity, and to obtain a sufficient amplification product for rare transcripts. Primers were designed using the Primer3 software [45], and checked for uniqueness by querying against the human genome.

\section{RACE protocol}

We applied the RNA-ligase-mediated RACE (RLM-RACE) system from Ambion. RNA sample from adult human retina was treated with DNAse I. After DNase treatment and inactivation, $10 \mu \mathrm{g}$ of total RNA was dephosphorylated for 60 min at $37^{\circ} \mathrm{C}$ with $10 \mathrm{U}$ Calf Intestinal Phosphatase to remove the $5^{\prime}$-phosphate from all RNA species except those that have a cap structure (present on all Pol II transcripts). RNA was then phenol/chloroform extracted, precipitated and re-suspended in water. Dephosphorylated RNA was then digested for $60 \mathrm{~min}$ at $37^{\circ} \mathrm{C}$ in a $10-\mu \mathrm{L}$ reaction with $10 \mathrm{U}$ tobacco acid pyrophosphatase. Subsequently the RNA was incubated for $60 \mathrm{~min}$ at $37^{\circ} \mathrm{C}$ with $1 \mathrm{U}$ T4 RNA ligase and $0.3 \mu \mathrm{g}$ of an RNA adapter (5' RACE Adapter 5'-GCU-GAU-GGC-GAU-GAA-UGA-ACA-CUGCGU-UUG-CUG-GCU-UUG-AUG-AAA-3'). After ligation, $180 \mathrm{ng}$ of RNA was incubated for $2 \mathrm{~min}$ at $75^{\circ} \mathrm{C}$ in the presence of $5 \mu \mathrm{M}$ random decamers in RT buffer. Single-stranded cDNA was generated by the addition of 100 $\mathrm{U}$ M-MLV RT and incubation at $42^{\circ} \mathrm{C}$ for $60 \mathrm{~min}$.

Amplification of 5' RACE cDNA was carried out using nested gene-specific primers and adapter specific primers and with $1 \mu \mathrm{l}$ of the first-strand cDNA reaction. PCR reactions were done in $50 \mu \mathrm{l}$ volume including $5 \mu \mathrm{l} 10 \times$ PCR Buffer supplied in the RLM kit, $4 \mu \mathrm{l}$ dNTP Mix $10 \mathrm{mM}, 2$ $\mu \mathrm{l} 5$ ' RACE gene-specific outer primer $(10 \mu \mathrm{M}), 2 \mu \mathrm{l} 5^{\prime}$ RACE Outer or Inner Primer $(10 \mu \mathrm{M})$, and $1 \mathrm{U}$ thermostable DNA polymerase. Cycling conditions were: $5 \mathrm{~min}$ initial denaturation at $94^{\circ} \mathrm{C}$ PCR followed by 35 cycles of $95^{\circ} \mathrm{C}$ for $30 \mathrm{~s}, 60-55^{\circ} \mathrm{C}$ (empirically determined) for $30 \mathrm{~s}$ (annealing), $72^{\circ} \mathrm{C}$ for $30 \mathrm{~s}$ (extension) and a final extension at $72^{\circ} \mathrm{C}$ for 7 mins. Amplified products were analysed on a $3 \%$ agarose gel and visualised by ethidium bromide staining.

\section{Cloning and sequencing of RACE products}

5' RACE products were cloned into pCR-2.1 vector (Invitrogen). $2 \mu \mathrm{L}$ of PCR reaction were incubated with $0.1 \mathrm{ng}$ of vector at $16^{\circ} \mathrm{C}$ over-night. Aliquots of the ligation were used to transform library efficiency chemically competent E. coli DH5 $\alpha$ (Invitrogen). 8 to 48 clones of each transformation were subjected to colony PCR and the inserts sequenced with standard M13 forward and reverse primers applying Big Dye Terminator v3.0 chemistry (Applied Biosystems). Sequencing products were separated and analysed on an ABI 3100 DNA sequencer.

\section{Sequence analysis}

Gene sequences and cDNA sequences, obtained using the RACE, were aligned to the human genome using BLAT. cDNA sequence was considered informative only if the following criteria were met: (I) the spliced sequence mapped to the same region of the genome as the gene sequence; (II) the product could be mapped uniquely to the genome with $>95 \%$ identity and (III) presence of the gene specific primer sequence and the 5' RACE Adapter primer sequence.

\section{Primer extension}

A fluorescein phosphoramidites (FAM)-labelled reverse primer was added to $10 \mu \mathrm{g}$ of DNAseI-treated total RNA to a final concentration of $5 \mathrm{nM}$. Samples were heated at $70^{\circ} \mathrm{C}$ for $5 \mathrm{~min}$ followed by $20 \mathrm{~min}$ incubation at $58^{\circ} \mathrm{C}$ and then allowed to cool for $15 \mathrm{~min}$ to room temperature. First strand cDNA synthesis was performed using Avian Myeloblastoma Virus (AMV) reverse transcriptase and 5x AMV-RT buffer (Promega) according to the manufacturer's instructions in a final volume of $60 \mu \mathrm{l}$. The primer extension reaction was done in two repeated reaction cycles. After an initial reverse transcription step (60 min at $42^{\circ} \mathrm{C}$ in a total volume of $50 \mu \mathrm{l}$ ), enzyme was replenished and the samples underwent a second extension reaction (60 min at $42^{\circ} \mathrm{C}$, adjusting the buffer to a total volume of $60 \mu \mathrm{l}$ ). Finally $3 \mu \mathrm{l}$ of $5 \mathrm{M} \mathrm{NaOH}$ was added to each cDNA sample, the reaction incubated at $37^{\circ} \mathrm{C}$ for $15 \mathrm{~min}$ and then neutralised with $16 \mu \mathrm{l}$ of $2 \mathrm{M}$ HEPES free acid. Extension products were purified using the columns AutoSeq G-50 (Amersham Pharmacia Biotech). Samples were separated on $50-\mathrm{cm}$ capillary columns in the POP4 acryl amide polymer (Applied Biosystems) on an ABI PRISM 3100 Genetic Analyser (Applied-Biosystems) Sequencer with GENESCAN 500-ROX added as size standard (Applied-Biosystems). The sequences of the gene specific reverse primers were: $R D H 125^{\prime}$ tgagcagcagcctgactctgagcaga gcccaga 3', CNGA3 5'atcttctcggtttgtcacatttagc 3', with 5 ' ends modified with the fluorescent molecule 6-FAM.

\section{Authors' contributions}

VR contributed to acquisition, analysis, interpretation of data and drafting the manuscript; RC has been involved in acquisition, analysis and interpretation of data and drafting the manuscript; $\mathrm{BW}$ conceived and coordinated the study and contributed materials and resources. All authors read and approved the final manuscript. 


\section{Additional material}

\section{Additional File 1}

List of genes selected for the study of identification of TSS. We provide in the list the Gene Symbol, Gene Name, Chromosomal location, Tissue/ cell type of expression, associated disease of the genes selected for our study. Abbreviation used in the table: RP: retinitis pigmentosa, CRD: cone-rod dystrophy, FF: fundus flavimaculatus, MD: macula degeneration, $R D$ : retinal dystrophy.

Click here for file

[http://www.biomedcentral.com/content/supplementary/1471-

2164-8-42-S1.doc]

\section{Additional File 2}

Figure 5: Schematic gene structure of DHRS3. Schema of the RefSeq, ESTs, exonic structure of new isoforms identified with Cap-finder RACE of human retina mRNA and a schema of the new genomic structure containing new TSSs (indicated by red arrows). The Cap-finder RACE allow us to confirm the first exon and TSS of this gene. We also show the presence in retina of an alternative form of transcript containing a first exon $21 \mathrm{~kb}$ downstream the annotated TSS.

Click here for file

[http://www.biomedcentral.com/content/supplementary/1471-

2164-8-42-S2.pdf]

\section{Additional File 3}

Figure 6: Schematic gene structure of ELOVL5. Schema of the RefSeq, ESTs, exonic structure of new isoforms identified with Cap-finder RACE of human retina mRNA and a schema of the new genomic structure containing new TSSs (indicated by red arrows): we show the presence in retina of an alternative transcript with a first exon downstream from the annotated one.

Click here for file

[http://www.biomedcentral.com/content/supplementary/14712164-8-42-S3.pdf]

\section{Additional File 4}

Figure 7: Schematic gene structure of KIFC3. Schema of the RefSeq, ESTs, exonic structure of new isoforms identified with Cap-finder RACE of human retina mRNA and a schema of the new genomic structure containing the TSSs (indicated by red arrows): figure shows two new isoforms lacking the 3 first exons annotated in the RefSeq. Both transcripts let us to define new TSSs located respectively $44 \mathrm{~kb}$ upstream and $27 \mathrm{~kb}$ downstream from the previous TSS.

Click here for file

[http://www.biomedcentral.com/content/supplementary/14712164-8-42-S4.pdf]

\section{Additional File 5}

Figure 8: Schematic gene structure of RCV1. Schema of the RefSeq, ESTs, exonic structure of new isoforms identified with Cap-finder RACE of human retina mRNA and a schema of the new genomic structure containing new TSSs (indicated by red arrows). The figure shows three isoforms that we obtained with RACE experiments: one form extending the first exon by 203 bp and the other two forms lacking the first annotated exons of the RefSeq and, respectively, containing one new first exon that splices with the second annotated one and one starting at the second exon but extending it by $80 \mathrm{bp}$. For both transcripts the TSS is downstream from the annotated one.

Click here for file

[http://www.biomedcentral.com/content/supplementary/1471-

2164-8-42-S5.pdf]

\section{Additional File 6}

Figure 9: Schematic gene structure of SLC24A2. Schema of the RefSeq, ESTs, exonic structure of new isoforms identified with Cap-finder RACE of human retina $m R N A$ and a schema of the new genomic structure containing new TSSs (indicated by red arrows): 4 new cDNAs clones from human retina identify 4 new TSSs for this gene. The transcripts contain two additional exons, $a$ and $b$, that are alternatively spliced.

Click here for file

[http://www.biomedcentral.com/content/supplementary/1471-

2164-8-42-S6.pdf]

\section{Additional File 7}

Sequence conservation of new first exon. Analysis of sequence conservation of the first new exons of the listed human transcript in comparison with a set of mammals (mouse, dog, cow). Numbers indicate percentage of identity.

Click here for file

[http://www.biomedcentral.com/content/supplementary/1471-

2164-8-42-S7.doc]

\section{Acknowledgements}

We thank Naomi Chadderton and Katja Koeppen for proofreading of the manuscript and Emanuela De Luca for help with the artwork.

This project is supported by: European Union Research Training Network 'RETNET' MRTN-CT-2003-504003

\section{References}

I. Smale ST, Kadonaga JT: The RNA polymerase II core promoter. Annu Rev Biochem 2003, 72:449-479.

2. Hahn S: Structure and mechanism of the RNA polymerase II transcription machinery. Nat Struct Mol Biol 2004, I I (5):394-403.

3. Venter JC, Adams MD, Myers EW, Li PW, Mural RJ, Sutton GG, Smith HO, Yandell M, Evans CA, Holt RA, Gocayne JD, Amanatides P, Ballew RM, Huson DH, Wortman JR, Zhang Q, Kodira CD, Zheng XH, Chen L, Skupski M, Subramanian G, Thomas PD, Zhang J, Gabor Miklos GL, Nelson C, Broder S, Clark AG, Nadeau J, McKusick VA Zinder N, Levine AJ, Roberts RJ, Simon M, Slayman C, Hunkapiller M, Bolanos R, Delcher A, Dew I, Fasulo D, Flanigan M, Florea L, Halpern A, Hannenhalli S, Kravitz S, Levy S, Mobarry C, Reinert K, Remington K, Abu-Threideh J, Beasley E, Biddick K, Bonazzi V, Brandon R, Cargill M, Chandramouliswaran I, Charlab R, Chaturvedi K, Deng Z, Di Francesco V, Dunn P, Eilbeck K, Evangelista C, Gabrielian AE, Gan W, Ge W, Gong F, Gu Z, Guan P, Heiman TJ, Higgins ME, Ji RR, Ke Z, Ketchum KA, Lai Z, Lei Y, Li Z, Li J, Liang Y, Lin X, Lu F, Merkulov GV, Milshina N, Moore HM, Naik AK, Narayan VA, Neelam B, Nusskern D, Rusch DB, Salzberg S, Shao W, Shue B, Sun J, Wang Z, Wang A, Wang X, Wang J, Wei M, Wides R, Xiao C, Yan C, Yao A, Ye J, Zhan M, Zhang W, Zhang H, Zhao Q, Zheng L, Zhong F, Zhong W, Zhu S, Zhao S, Gilbert D, Baumhueter S, Spier G, Carter C, Cravchik A, Woodage T, Ali F, An H, Awe A, Baldwin D, Baden H, Barnstead M, Barrow I, Beeson K, Busam D, Carver A, Center A, Cheng ML, Curry L, Danaher S, Davenport L, Desilets R, Dietz S, Dodson K, Doup L, Ferriera S, Garg N, Gluecksmann A, Hart B, Haynes J, Haynes C, Heiner C, Hladun S, Hostin D, Houck J, Howland T, Ibegwam C, Johnson J, Kalush F, Kline L, Koduru S, Love A, Mann F, May D, McCawley S, Mclntosh T, McMullen I, Moy M, Moy L, Murphy B, Nelson K, Pfannkoch C, Pratts E, Puri V, Qureshi H, Reardon M, Rodriguez $R$, Rogers $Y H$, Romblad D, Ruhfel B, Scott R, Sitter C Smallwood M, Stewart E, Strong R, Suh E, Thomas R, Tint NN, Tse S, Vech C, Wang G, Wetter J, Williams S, Williams M, Windsor S, WinnDeen E, Wolfe K, Zaveri J, Zaveri K, Abril JF, Guigo R, Campbell MJ, Sjolander KV, Karlak B, Kejariwal A, Mi H, Lazareva B, Hatton T, Narechania A, Diemer K, Muruganujan A, Guo N, Sato S, Bafna V, Istrail S, Lippert R, Schwartz R, Walenz B, Yooseph S, Allen D, Basu A, Baxendale J, Blick L, Caminha M, Carnes-Stine J, Caulk P, Chiang 
YH, Coyne M, Dahlke C, Mays A, Dombroski M, Donnelly M, Ely D, Esparham S, Fosler C, Gire H, Glanowski S, Glasser K, Glodek A, Gorokhov M, Graham K, Gropman B, Harris M, Heil J, Henderson S, Hoover J, Jennings D, Jordan C, Jordan J, Kasha J, Kagan L, Kraft C, Levitsky A, Lewis M, Liu X, Lopez J, Ma D, Majoros W, McDaniel J, Murphy S, Newman M, Nguyen T, Nguyen N, Nodell M, Pan S, Peck J, Peterson M, Rowe W, Sanders R, Scott J, Simpson M, Smith T, Sprague A, Stockwell T, Turner R, Venter E, Wang M, Wen M, Wu $D$, Wu M, Xia A, Zandieh A, Zhu X: The sequence of the human genome. Science 200I, 29I(5507): |304-I35I.

4. Lander ES, Linton LM, Birren B, Nusbaum C, Zody MC, Baldwin J, Devon K, Dewar K, Doyle M, FitzHugh W, Funke R, Gage D, Harris K, Heaford A, Howland J, Kann L, Lehoczky J, LeVine R, McEwan P, McKernan K, Meldrim J, Mesirov JP, Miranda C, Morris W, Naylor J, Raymond C, Rosetti M, Santos R, Sheridan A, Sougnez C, StangeThomann N, Stojanovic N, Subramanian A, Wyman D, Rogers J, Sulston J, Ainscough R, Beck S, Bentley D, Burton J, Clee C, Carter N, Coulson A, Deadman R, Deloukas P, Dunham A, Dunham I, Durbin R, French L, Grafham D, Gregory S, Hubbard T, Humphray S, Hunt A, Jones M, Lloyd C, McMurray A, Matthews L, Mercer S, Milne S, Mullikin JC, Mungall A, Plumb R, Ross M, Shownkeen R, Sims S, Waterston RH, Wilson RK, Hillier LW, McPherson JD, Marra MA, Mardis ER, Fulton LA, Chinwalla AT, Pepin KH, Gish WR, Chissoe SL, Wendl MC, Delehaunty KD, Miner TL, Delehaunty A, Kramer JB, Cook LL, Fulton RS, Johnson DL, Minx PJ, Clifton SW, Hawkins T, Branscomb E, Predki P, Richardson P, Wenning S, Slezak T, Doggett $\mathrm{N}$, Cheng JF, Olsen A, Lucas S, Elkin C, Uberbacher E, Frazier M, Gibbs RA, Muzny DM, Scherer SE, Bouck JB, Sodergren E], Worley KC, Rives CM, Gorrell JH, Metzker ML, Naylor SL, Kucherlapati RS, Nelson DL, Weinstock GM, Sakaki Y, Fujiyama A, Hattori M, Yada T, Toyoda A, Itoh T, Kawagoe C, Watanabe H, Totoki Y, Taylor T, Weissenbach J, Heilig R, Saurin W, Artiguenave F, Brottier P, Bruls T, Pelletier E, Robert C, Wincker P, Smith DR, Doucette-Stamm L, Rubenfield M, Weinstock K, Lee HM, Dubois J, Rosenthal A, Platzer M, Nyakatura G, Taudien S, Rump A, Yang H, Yu J, Wang J, Huang G, Gu J, Hood L, Rowen L, Madan A, Qin S, Davis RW, Federspiel NA, Abola AP, Proctor MJ, Myers RM, Schmutz J, Dickson M, Grimwood J, Cox DR, Olson MV, Kaul R, Raymond C, Shimizu N, Kawasaki K, Minoshima S, Evans GA, Athanasiou M, Schultz R, Roe BA, Chen F, Pan H, Ramser J, Lehrach H, Reinhardt R, McCombie WR, de la Bastide M, Dedhia N, Blocker H, Hornischer K, Nordsiek G, Agarwala R, Aravind L, Bailey JA, Bateman A, Batzoglou S, Birney E, Bork P, Brown DG, Burge CB, Cerutti L, Chen HC, Church D, Clamp M, Copley RR, Doerks T, Eddy SR, Eichler EE, Furey TS, Galagan J, Gilbert JG, Harmon $C$, Hayashizaki $Y$, Haussler D, Hermjakob $H$, Hokamp K, Jang W, Johnson LS, Jones TA, Kasif S, Kaspryzk A, Kennedy S, Kent WJ, Kitts P, Koonin EV, Korf I, Kulp D, Lancet D, Lowe TM, McLysaght A, Mikkelsen T, Moran JV, Mulder N, Pollara VJ, Ponting CP, Schuler G, Schultz J, Slater G, Smit AF, Stupka E, Szustakowski J, Thierry-Mieg D, Thierry-Mieg J, Wagner L, Wallis J, Wheeler R, Williams A, Wolf YI, Wolfe KH, Yang SP, Yeh RF, Collins F, Guyer MS, Peterson J, Felsenfeld A, Wetterstrand KA, Patrinos A, Morgan MJ, de Jong P, Catanese J], Osoegawa K, Shizuya H, Choi S, Chen YJ: Initial sequencing and analysis of the human genome. Nature 200I, 409(6822):860-92I.

5. Trinklein ND, Aldred SJ, Saldanha AJ, Myers RM: Identification and functional analysis of human transcriptional promoters. Genome Res 2003, I3(2):308-312.

6. Davuluri RV, Grosse I, Zhang MQ: Computational identification of promoters and first exons in the human genome. Nat Genet 200I, 29(4):4I2-4I7.

7. Sonnenburg S, Zien A, Ratsch G: ARTS: accurate recognition of transcription starts in human. Bioinformatics 2006, 22(14): e472-80.

8. Suzuki Y, Yamashita R, Sugano S, Nakai K: DBTSS, DataBase of Transcriptional Start Sites: progress report 2004. Nucleic Acids Res 2004, 32(Database issue):D78-8I.

9. Cheng J, Kapranov P, Drenkow J, Dike S, Brubaker S, Patel S, Long J, Stern D, Tammana H, Helt G, Sementchenko V, Piccolboni A, Bekiranov S, Bailey DK, Ganesh M, Ghosh S, Bell I, Gerhard DS, Gingeras TR: Transcriptional maps of 10 human chromosomes at 5-nucleotide resolution. Science 2005, 308(5725): | | 49-I I 54.

10. Carninci P, Sandelin A, Lenhard B, Katayama S, Shimokawa K, Ponjavic J, Semple CA, Taylor MS, Engstrom PG, Frith MC, Forrest AR, Alkema WB, Tan SL, Plessy C, Kodzius R, Ravasi T, Kasukawa T, Fukuda S, Kanamori-Katayama M, Kitazume Y, Kawaji H, Kai C, Nakamura M,
Konno H, Nakano K, Mottagui-Tabar S, Arner P, Chesi A, Gustincich S, Persichetti F, Suzuki H, Grimmond SM, Wells CA, Orlando V, Wahlestedt C, Liu ET, Harbers M, Kawai J, Bajic VB, Hume DA, Hayashizaki Y: Genome-wide analysis of mammalian promoter architecture and evolution. Nat Genet 2006.

II. Schulz HL, Goetz T, Kaschkoetoe J, Weber BH: The Retinome defining a reference transcriptome of the adult mammalian retina/retinal pigment epithelium. BMC Genomics 2004, 5(I):50.

12. Blackshaw S, Harpavat S, Trimarchi J, Cai L, Huang H, Kuo WP, Weber G, Lee K, Fraioli RE, Cho SH, Yung R, Asch E, Ohno-Machado L, Wong WH, Cepko CL: Genomic analysis of mouse retinal development. PLoS Biol 2004, 2(9):E247.

13. Blackshaw S, Fraioli RE, Furukawa T, Cepko CL: Comprehensive analysis of photoreceptor gene expression and the identification of candidate retinal disease genes. Cell 200I, 107(5):579-589.

14. Chowers I, Gunatilaka TL, Farkas RH, Qian J, Hackam AS, Duh E, Kageyama M, Wang C, Vora A, Campochiaro PA, Zack DJ: Identification of novel genes preferentially expressed in the retina using a custom human retina cDNA microarray. Invest Ophthalmol Vis Sci 2003, 44(9):3732-374I.

15. Lord-Grignon J, Tetreault N, Mears AJ, Swaroop A, Bernier G: Characterization of new transcripts enriched in the mouse retina and identification of candidate retinal disease genes. Invest Ophthalmol Vis Sci 2004, 45(9):3313-3319.

16. Yu J, Farjo R, MacNee SP, Baehr W, Stambolian DE, Swaroop A: Annotation and analysis of 10,000 expressed sequence tags from developing mouse eye and adult retina. Genome Biol 2003, 4(I0):R65.

17. Schmid CD, Perier R, Praz V, Bucher P: EPD in its twentieth year: towards complete promoter coverage of selected model organisms. Nucleic Acids Res 2006, 34(Database issue):D82-5.

18. Wissinger B, Gamer D, Jagle H, Giorda R, Marx T, Mayer S, Tippmann $S$, Broghammer M, Jurklies B, Rosenberg T, Jacobson SG, Sener EC, Tatlipinar S, Hoyng CB, Castellan C, Bitoun P, Andreasson S, Rudolph G, Kellner U, Lorenz B, Wolff G, Verellen-Dumoulin C, Schwartz M, Cremers FP, Apfelstedt-Sylla E, Zrenner E, Salati R, Sharpe LT, Kohl $\mathrm{S}$ : CNGA3 mutations in hereditary cone photoreceptor disorders. Am J Hum Genet 200I, 69(4):722-737.

19. Haeseleer F, Jang GF, Imanishi Y, Driessen CA, Matsumura M, Nelson PS, Palczewski K: Dual-substrate specificity short chain retinol dehydrogenases from the vertebrate retina. J Biol Chem 2002, 277(47):45537-45546.

20. Janecke AR, Thompson DA, Utermann G, Becker C, Hubner CA, Schmid E, McHenry CL, Nair AR, Ruschendorf F, Heckenlively J, Wissinger B, Nurnberg P, Gal A: Mutations in RDH 2 encoding a photoreceptor cell retinol dehydrogenase cause childhoodonset severe retinal dystrophy. Nat Genet 2004, 36(8):850-854.

21. Perrault I, Hanein S, Gerber S, Barbet F, Ducroq D, Dollfus H, Hamel C, Dufier JL, Munnich A, Kaplan J, Rozet JM: Retinal dehydrogenase 12 (RDHI2) mutations in leber congenital amaurosis. Am J Hum Genet 2004, 75(4):639-646.

22. Haeseleer F, Huang J, Lebioda L, Saari JC, Palczewski K: Molecular characterization of a novel short-chain dehydrogenase/ reductase that reduces all-trans-retinal. J Biol Chem 1998, 273(34):21790-2I 799 .

23. Yoshida S, Mears AJ, Friedman JS, Carter T, He S, Oh E, Jing Y, Farjo R, Fleury G, Barlow C, Hero AO, Swaroop A: Expression profiling of the developing and mature Nrl-/- mouse retina: identification of retinal disease candidates and transcriptional regulatory targets of Nrl. Hum Mol Genet 2004, I 3(I 4): | 487-I 503.

24. Barragan I, Marcos I, Borrego S, Antinolo G: Mutation screening of three candidate genes, ELOVL5, SMAPI and GLULDI in autosomal recessive retinitis pigmentosa. Int J Mol Med 2005, 16(6): II63-1167.

25. Hoang E, Bost-Usinger L, Burnside B: Characterization of a novel C-kinesin (KIFC3) abundantly expressed in vertebrate retina and RPE. Exp Eye Res 1999, 69(1):57-68.

26. Maeda A, Ohguro H, Maeda T, Wada I, Sato N, Kuroki Y, Nakagawa $T$ : Aberrant expression of photoreceptor-specific calciumbinding protein (recoverin) in cancer cell lines. Cancer Res 2000, 60(7): 1914-1920.

27. Wiechmann A, Howard E: Functional analysis of the human recoverin gene promoter. Curr Eye Res 2003, 26(I):25-32. 
28. Li XF, Kraev AS, Lytton J: Molecular cloning of a fourth member of the potassium-dependent sodium-calcium exchanger gene family, NCKX4. J Biol Chem 2002, 277(50):484I0-484I7.

29. Sharon D, Yamamoto H, McGee TL, Rabe V, Szerencsei RT, Winkfein RJ, Prinsen CF, Barnes CS, Andreasson S, Fishman GA, Schnetkamp PP, Berson EL, Dryja TP: Mutated alleles of the rod and cone $\mathrm{Na}-\mathrm{Ca}+\mathrm{K}-e x c h a n g e r$ genes in patients with retinal diseases. Invest Ophthalmol Vis Sci 2002, 43(6): 1971-1979.

30. Frith MC, Ponjavic J, Fredman D, Kai C, Kawai J, Carninci P, Hayashizaki Y, Sandelin A: Evolutionary turnover of mammalian transcription start sites. Genome Res 2006, 16(6):713-722.

31. King DC, Taylor J, Elnitski L, Chiaromonte F, Miller W, Hardison RC: Evaluation of regulatory potential and conservation scores for detecting cis-regulatory modules in aligned mammalian genome sequences. Genome Res 2005, I 5(8): 105I-1060.

32. Dike S, Balija VS, Nascimento LU, Xuan Z, Ou J, Zutavern T, Palmer LE, Hannon G, Zhang MQ, McCombie WR: The mouse genome: experimental examination of gene predictions and transcriptional start sites. Genome Res 2004, I 4(I 2):2424-2429.

33. Oyama M, Itagaki $C$, Hata $H$, Suzuki $Y$, Izumi $T$, Natsume $T$, Isobe $T$, Sugano S: Analysis of small human proteins reveals the translation of upstream open reading frames of mRNAs. Genome Res 2004, I 4( I OB):2048-2052

34. Rogozin IB, Kochetov AV, Kondrashov FA, Koonin EV, Milanesi L: Presence of ATG triplets in 5' untranslated regions of eukaryotic cDNAs correlates with a 'weak' context of the start codon. Bioinformatics 200 I, I 7(10):890-900.

35. Sachs MS, Geballe AP: Downstream control of upstream open reading frames. Genes Dev 2006, 20(8):915-921.

36. Hochheimer A, Tjian R: Diversified transcription initiation complexes expand promoter selectivity and tissue-specific gene expression. Genes Dev 2003, I7(II):1309-1320.

37. Zhang T, Haws $P$, Wu Q: Multiple variable first exons: a mechanism for cell- and tissue-specific gene regulation. Genome Res 2004, I 4(I):79-89.

38. Bortoluzzi S, Coppe A, Bisognin A, Pizzi C, Danieli GA: A multistep bioinformatic approach detects putative regulatory elements in gene promoters. BMC Bioinformatics 2005, 6:121.

39. Halees AS, Leyfer D, Weng Z: PromoSer: A large-scale mammalian promoter and transcription start site identification service. Nucleic Acids Res 2003, 3 I ( I 3):3554-3559.

40. Eukaryotic Promoter Database Current Release 87 [http:// www.epd.isb-sib.ch]

41. DBTSS [http://dbtss.hgc.jp]

42. Kent W]: BLAT--the BLAST-like alignment tool. Genome Res 2002, I 2(4):656-664.

43. AceView [http://www.ncbi.nlm.nih.gov//EB/Research/Acembly/]

44. BioEdit pairwise and multiple alignments [http:// www.mbio.ncsu.edu/BioEdit/bioedit.html]

45. Primer3

primer3 www.cgi] [http://frodo.wi.mit.edu/cgi-bin/primer3/

\section{Publish with Bio Med Central and every scientist can read your work free of charge}

"BioMed Central will be the most significant development for disseminating the results of biomedical research in our lifetime. "

Sir Paul Nurse, Cancer Research UK

Your research papers will be:

- available free of charge to the entire biomedical community

- peer reviewed and published immediately upon acceptance

- cited in PubMed and archived on PubMed Central

- yours - you keep the copyright
BioMedcentral 